\title{
A neonate with facial asymmetry
}

\author{
Anand Kumar Gupta, ${ }^{1}$ Rashmi Ranjan Das, ${ }^{2}$ Shasanka Shekhar Panda, ${ }^{3}$ \\ Meely Panda ${ }^{4}$
}

${ }^{1}$ Department of Neonatology, All India Institute of Medical Sciences (AlIMS), New Delhi, India

2Department of Paediatrics, All India Institute of Medical Sciences (AllMS),

Bhubaneshwar, Odisha, India ${ }^{3}$ Department of Pediatric Surgery, All India Institute of Medical Sciences (AllMS), New Delhi, India

${ }^{4}$ Department of Community Medicine, Pandit Bhagwat Dayal Sharma Post Graduate Institute of Medical Sciences, Rohtak, Haryana, India

\section{Correspondence to}

Dr Shasanka Shekhar Panda, drshasank_aiims@yahoo.co.in

\section{DESCRIPTION}

A 3-day-old male neonate was presented with facial asymmetry and difficulty in breastfeeding since birth. He was born by assisted vaginal delivery to a primigravida mother with a history of difficult labour. On examination, there was facial asymmetry with a deviation of the angle of mouth towards the right side. The baby was not able to close the left-side eyelid, and the mouth was not moving down the same way on both sides. There was almost no movement on the left side of the face (figure 1). The rest of the systemic examination was unremarkable. A diagnosis of complete congenital lower motor neuron-type left facial nerve paralysis was made. Brainstem evoked response audiometry (BERA) and MRI brain was normal. He was kept under follow-up after prescribing artificial tears and lubricants along with eye patches during sleep. On the last follow-up at 2 months of age, the facial palsy has totally resolved.

Congenital facial palsy (CFP) is present at birth or shortly thereafter. ${ }^{1}$ The incidence is around 2.1/1000 live-births. ${ }^{1}$ Causes include perinatal trauma, intrauterine posture, intrapartum compression and congenital aplasia of the nucleus (most commonly bilateral). ${ }^{1}$ The majority $(78-90 \%)$ are

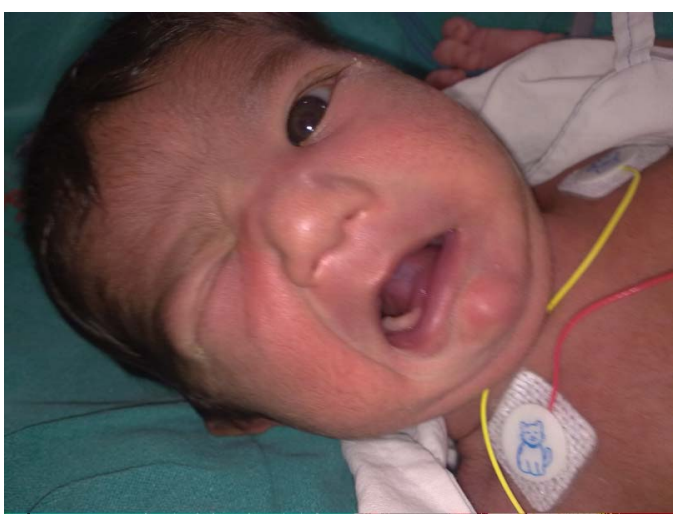

Figure 1 Facial asymmetry with deviation of the angle of mouth towards the right side. Inability to close the left-side eyelids, and the mouth not moving down the same way on both sides. There is almost no movement on the left side of the face. associated with birth trauma. Cardiofacial, Moebius, Poland's and Goldenhar's syndromes encompass CFP as part of their symptoms. ${ }^{2}$ An important differential diagnosis is congenital 'facial asymmetry during cry' due to a congenital absence or weakness of depressor anguli oris muscle (cardiofacial syndrome), so when the child is crying the corner of the mouth does not lower leading to facial asymmetry. ${ }^{1}$ In congenital or syndromic causes, the facial palsy is not reversible. ${ }^{2}$

\section{Learning points}

- In a new born with congenital facial paralysis early establishment of aetiology is very important to distinguish between traumatic and developmental causes, as this will determine the course of disease process and treatment plan.

- A careful history and full-body examination may reveal the causes of the paralysis but additional investigations may be necessary (electromyography (EMG), nerve conduction studies, CT and MRI).

- Most often children are born with facial nerve paralysis (typically affecting one side only) that has no identifiable cause and treatment is difficult since a complete and accurate assessment of the patient cannot realistically take place before the child has reached a cooperative age.

Competing interests None.

Patient consent Obtained.

Provenance and peer review Not commissioned; externally peer reviewed.

\section{REFERENCES}

1 Pavlou E, Gkampeta A, Arampatzi M. Facial nerve palsy in childhood. Brain Dev 2011;33:644-50.

2 Alrashdi IS, Rich P, Patton MA. A family with hereditary congenital facial paresis and a brief review of the literature. Clin Dysmorphol 2010;19:198-201. 


\section{Images in...}

Copyright 2013 BMJ Publishing Group. All rights reserved. For permission to reuse any of this content visit http://group.bmj.com/group/rights-licensing/permissions.

BMJ Case Report Fellows may re-use this article for personal use and teaching without any further permission.

Become a Fellow of BMJ Case Reports today and you can:

- Submit as many cases as you like

- Enjoy fast sympathetic peer review and rapid publication of accepted articles

- Access all the published articles

- Re-use any of the published material for personal use and teaching without further permission

For information on Institutional Fellowships contact consortiasales@bmjgroup.com

Visit casereports.bmj.com for more articles like this and to become a Fellow 